Article

\title{
Sustainable Feasibility of Carbon Trading Policy on Heterogenetic Economic and Industrial Development
}

\author{
Haoran Zhang ${ }^{1}\left[\right.$, Rongxia Zhang ${ }^{1}$, Guomin $\mathrm{Li}^{1}{ }^{1}$, Wei $\mathrm{Li}^{1, *}$ and Yongrok Choi ${ }^{2, *} \mathbb{C}$ \\ 1 School of Economics and Management, Taiyuan University of Technology; Taiyuan 030024, China; \\ zhanghaoran0205@126.com (H.Z.); zhangrongxia@tyut.edu.cn (R.Z.); liguomin@tyut.edu.cn (G.L.) \\ 2 Department of International Trade, Inha University, Incheon 402-751, Korea \\ * Correspondence: liwei01@tyut.edu.cn (W.L.); yrchoi@inha.ac.kr (Y.C.); \\ Tel.: +86-0351-317-6718 (W.L.); +82-32-860-7760 (Y.C.)
}

Received: 13 November 2019; Accepted: 2 December 2019; Published: 3 December 2019

\begin{abstract}
A carbon emission trading system (ETS) is an effective market mechanism for promoting the reduction of global greenhouse gas emissions and achieving sustainable development between the economy and the environment. To analyze the emissions reduction effect and economic effect of China's ETS and further discuss the mechanisms of economic development differences and industrial development differences on the final effect of the policy, this study adopts the propensity score matching-difference in differences method and triple difference method. The empirical results show the following: (1) The ETS can simultaneously achieve both the emissions reduction effect and economic effect when key control variables are included. (2) The population, carbon emissions intensity and per capita GDP have significant positive impacts on carbon emissions; the environmental pollution control intensity, research structure, and research intensity have negative impacts on carbon emissions; and the capita stock, employment, and energy consumption have significant positive economic effects. (3) The ETS has a stronger inhibitory effect on the provinces with higher levels of economic and service development compared to the provinces with lower levels of economic and service development. In contrast, the policy has a weaker inhibitory effect on provinces with higher levels of industrial and construction development compared with the lower level provinces.
\end{abstract}

Keywords: heterogeneity; Porter effect; PSM-DID; DDD

\section{Introduction}

Greenhouse gas emissions will aggravate the environmental negative externalities on global economic development and restrict the sustainable development of human society. A carbon emission trading system (EST) is a powerful channel for emission reduction and alleviating global warming [1]. According to relevant authorities, the global carbon trade system reached 150 billion tons in 2012, and it has replaced the oil market as the largest trading market. With the completion of relevant agreements and the construction of ETS systems in the major economies of the world, the trading volume in 2020 is expected to approach 3.5 trillion. Following the "Kyoto Protocol" and the "United Nations Framework Convention on Climate Change," the European Union fully launched its ETS in 2005, which was the first ETS in the world and is the international ETS with the most successful operations and widest coverage [2]. New Zealand, South Korea, and other countries have launched mandatory nationwide domestic ETSs. Starting with the voluntary Chicago Climate Exchange (CCX), the United Sates has tried to establish mandatory systems and has gradually established regional ETSs, such as the Regional Greenhouse Gas Initiative (RGGI).

As the largest carbon emitter in the world, the establishment of an ETS in China will have a significant impact on global carbon emissions control [3]. China has formally launched a pilot project 
for ETS from 2013 to 2014, which included Beijing, Tianjin, Shanghai, Chongqing, Guangdong, Hubei and Shenzhen, and gradually began expanding its ETS nationwide starting in 2017. In the initial implementation of the ETS, Shenzhen, Beijing, and Shanghai included many non-industrial enterprises, covering construction and service industries; while Guangdong, Tianjin, Hubei, and Chongqing were mainly industrial enterprises. The principle of quota allocation is mainly based on the baseline method and the historical intensity method, using a combination of free allocation and auction. It will cover approximately 3.5 billion tons of carbon emissions from more than 1700 enterprises in the electric power industry, which accounts for nearly $39 \%$ of the $\mathrm{CO}_{2}$ emissions in China, and the trading volume will far surpass the current largest ETS- the EU-ETS.

However, the full establishment of China's ETS will face tremendous challenges. Due to the short implementation time of China's ETS and its immature mechanism construction, it is difficult to accurately calculate the emissions standards included in the industry except for the power industry. Although there are various types of carbon financial products, the actual scale of transactions on the market is limited. Therefore, there are many uncertainties about the effects of ETS. How can emission reduction be achieved without negative economic effects? Could it achieve some positive economic effects? Most scholars generally believe that pilot projects can achieve emission reduction, but they have different opinions on whether they can simultaneously achieve economic effects, and some of them think that environmental regulations will decrease GDP [4-6]. In contrast, some believe that reasonable environmental regulations would stimulate the "innovation compensation" effect, which would compensate for the related costs of environmental regulations and also promote carbon productivity and international competitiveness. Thus, it would promote positive economic effects $[7,8]$, that is, the realization of the famous "Porter hypothesis" effect $[9,10]$. The existing literature mainly focus on the evaluation of the effect of a pilot project based on the "Porter hypothesis," but there are no deep studies on the heterogeneity of economic development and industrial development. Do the economic development differences affect the final implementation effect of ETS? How do the industrial development differences in pilot provinces and cities affect the emission reduction effect and economic effect?

This study is focused on solving these problems as follows. (1) Twelve control variables are selected from five perspectives in an attempt to verify the existence of the "Porter hypothesis" in China's ETS pilot provinces and cities. (2) The heterogeneity of the final effect of the ETS on the pilot provinces and cities with different levels of economic development and industrial development is also studied. For the first problem, the propensity score matching difference in differences (PSM-DID) method under various matching conditions is adopted. For the second problem, the triple difference (DDD) method is applied to show the heterogeneity of the policy effect and evaluate the specific mechanism.

The composition of other parts are as follows. Section 2 conducts a related literature review with respect to ETS implementation effect and relevant policy evaluation methods. Section 3 lists the research method and data. Section 4 demonstrates the empirical results. Section 5 presents the discussion. Conclusions and policy suggestions are offered in Section 5.

\section{Literature Review}

The ultimate effect of an ETS has always been a topic of discussion in the academic community. As with other environmental regulation policies, scholars are focused on whether an ETS can simultaneously generate economic dividends while reducing carbon emissions, thus achieving sustainable social development. Early neoclassical economics suggested that environmental regulations had negative impacts on a country's economic welfare [11,12]. However, Porter, whose work was based on dynamic standards in 1991, believed that reasonable environmental regulations could encourage enterprises to optimize their resource allocations and conduct technological innovation, thus stimulating the "innovation compensation" effect. The benefits" of such technological innovation could both offset the costs of complying with environmental regulations and achieve a win-win situation between the environment and the economy by improving productivity and international 
competitiveness. The main studies on the validity of ETS, based on the "Porter hypothesis," are as follows. Zhang et al. simulated the national ETS scenarios of China by applying the stochastic frontier approach (SFA), the difference model, and nonlinear programming, and their conclusions show that the interprovincial carbon emissions could be decreased by $19.79 \%$ while the carbon intensity was decreased by $25.24 \%$ under the constraints of GDP output, economic growth, and environmental regulation [13]. Wang et al. used the panel data of 30 provinces in China and adopted the PSM-DID method to study the effect of the China ETS provincial pilot project, and the conclusion showed that a win-win situation between the environment and the economy can be achieved; thus, the goal of low-carbon economic transformation can be successfully accomplished [14]. Zhou et al. adopted the same method to study the China ETS pilot, and they found that the policy could reduce the carbon intensity in the pilot regions by an average of 0.026 tons/RMB 10,000 yuan per year. It was also found that the impact of the industrial structure on carbon intensity was greater than those on the energy structure and energy intensity [15]. Dong et al. adopted the DID and DEA models separately to analyze whether China's ETS pilot policy could generate both environmental and economic welfare improvements. The study showed that the ETS could significantly reduce the carbon emissions in the pilot regions in the short term, but it could not promote GDP growth. In the long run, the ETS could achieve economic welfare and environmental welfare improvements, thus achieving the "Porter effect" [16]. Zhang et al. focused on environmental innovation and estimated the effect of environmental innovation and the initial carbon emission trading (CET) Plan on emission reduction by using the system generalized method of moments (SGMM) and the PSM-DID model, respectively [17]. The study shows that the energy efficiency, innovative knowledge, and innovative resource factors can hinder carbon emissions, and there is a lag period in the carbon reduction effect from environmental regulations. From the perspective of different industries, scholars have studied the impacts of ETS on different industries and human behavior. It is generally believed that an ETS can significantly reduce pollution and promote sustainable development [18-23]. Some scholars also studied the efficiency of China's ETS pilot provinces and cities with respect to the carbon price. Although inefficiency generally exists, the efficiency of most pilot provinces and cities increases over time [24-29]. Existing studies mainly focus on evaluating the mechanism of the effect of an ETS on the carbon intensity, carbon emissions, and GDP. The literature related to industries is mostly analyzed from a single industry perspective. It is generally believed that policies can hinder carbon emissions and carbon intensity, but there are different viewpoints on the economic effects of an ETS, and some verify the "Porter hypothesis" from different perspectives [30,31].

The difference in differences (DID) method is often used to evaluate a policy's effect because it can avoid the endogeneity problems of utilizing a policy as an explanatory variable. Yang et al. studied the impact of the carbon intensity constraint policy (CICP) that was proposed by China in 2009 on industry and found that the industrial green production performance (denoted as GPP) in China decreased after a short increase, and the increase of industrial output was the key driving factor for improving the GPP [32]. Tu and Chen studied whether the SO2 trading system pilot could stimulate the "Porter effect" in China by controlling regional environmental regulations and other explanatory variables and found that the emissions reduction effect is not sufficient to achieve the "Porter effect" [33]. The DDD method adds a dummy variable on the basis of the DID model, which can solve the situation that the common trend hypothesis is not established for the DID; therefore, it is commonly used to solve the related heterogeneity problems. Liu and Zhang analyzed the impact of an ETS on the research and development (R\&D) innovation of A-share listed companies on the micro level, and found that an ETS policy can improve the R\&D investment intensity of the treatment group enterprises; however, it has a significant positive effect only on the innovation investment of large-scale enterprises, and it has no significant effect on the R\&D innovation of small-scale enterprises [34]. Ren et al. adopted the panel data of provinces and cities in China to study the effect of an $\mathrm{SO} 2$ trading system pilot policy on the total factor productivity (TFP) of enterprises in 2017, and they found that the policy mainly affects TFP by promoting enterprises' technological innovation and optimizing resource allocation efficiency [7]. 
Furthermore, with respect to the type of enterprise ownership, non-state-owned enterprises were more sensitive to the policy than state-owned enterprises. In addition, from the perspective of environmental enforcement, the higher the environmental enforcement is, the greater the role that enforcement plays in promoting TFP [7]. The above-mentioned literature on the DID model mainly focuses on the overall implementation effect of a certain policy, but it seldom involves issues related to industry differences and enterprise differences. The literature on the DDD model mainly focuses on the heterogeneity of enterprises. It is generally believed that state-owned enterprises and large-scale enterprises have greater advantages than non-state-owned enterprises and small-scale enterprises. However, there is insufficient research on the specific economic differences and industrial differences. On the basis of previous studies, this study systematically analyzes the "Porter effect" of China's ETS pilot projects and further discusses the mechanism of the effects of economic development differences and industrial development differences on the current regional ETS.

\section{Method and Data}

\subsection{PSM-DID Model}

The DID method has been widely used to evaluate the ultimate effect of the implementation of a public policy. The principle is based on the counterfactual framework that evaluates the variability of the observations in both cases with and without the policy. The principle is based on the counterfactual framework that constructs a treatment group with policy interventions and a control group without policy interventions. If the common trend hypothesis is satisfied, that is, there is no significant difference between the treatment group and the control group before the policy's implementation, then the change of the treatment group before and after the experimental period can be considered to be the effect of the policy's implementation (counterfactual results). By comparing the differences of the treatment group and control group, we can get the actual effect of the policy shock [35-38]. By introducing the PSM model, a random allocation can be achieved by checking the systematic differences between the samples before and after matching, thus eliminating the endogeneity problems that may exist in the model and ensuring the effectiveness of the PSM-DID model [39]. In this study, the pilot projects of ETS in Beijing, Tianjin, Shanghai, Chongqing, Guangdong, Hubei, and Shenzhen are regarded as a natural experiment. The treatment group is the provinces and cities that implement the ETS pilot policy, while the control group is the other provinces and cities that have not implemented the policy (excluding Tibet, Hong Kong, Macao, and Taiwan). To fully reflect the true implementation effect of the policy and consider the actual operating period of the ETS in Chongqing and Hubei, 2014 is regarded as the starting year of the pilot programs. After introducing the empirical dummy variables, the model is formulated as follows:

$$
\begin{aligned}
& C_{i t}=\alpha_{0}+\alpha_{1} \operatorname{prov}_{i} \times \text { peri }_{t}+\alpha_{2} \text { Control }_{i t}+\eta_{i}+\gamma_{t}+\mu_{i t} \\
& Y_{i t}=\beta_{0}+\beta_{1} \operatorname{prov}_{i} \times \text { peri }_{t}+\beta_{2} \text { Control }_{i t}+\eta_{i}+\gamma_{t}+\mu_{i t}
\end{aligned}
$$

here, "prov" represents the province dummy variable, the province i belong to pilot projects is set to 1 , and the others are set to 0 . "peri" represents the time dummy variable, the pre-pilot period is 2005-2013, and the post-pilot period is 2014-2017, the year $t$ represents post-pilot is 1, while represents pre-pilot is 0 . The interaction term defined as " $\mathrm{Z}=$ prov $\times$ peri." Cit represents the $\mathrm{CO} 2$ emissions of province $i$ in year $t$, which measures the emissions reduction effect of the ETS pilot. Yit represents the GDP of province $i$ in year $t$, which measuring the economic effect of the ETS pilot. Control represents the control variables affecting the emissions reduction effect and economic effect. $\eta$ is the provincial fixed effect, $\gamma$ is the time fixed effect, and $\mu$ is the time disturbance term. Based on Equations (1) and (2), we are interested in the coefficient of the interaction term $Z$, which indicates the difference between the pilot provinces and cities and non-pilot provinces and cities during the experimental period, excluding the difference of the pilot provinces and cities and non-pilot provinces and cities 
outside the experimental period, so as to correctly evaluate the carbon reduction pilot's emission reduction and economic effects.

\subsection{DDD Model}

In the estimation of the above mentioned DID model, for the purpose of further analyzing the mechanism of the effects of the economic development differences and industrial development differences on the ETS pilot policy, this study introduces dummy variables for the economic development differences and industrial development differences to construct a DDD model as follows:

$$
\begin{aligned}
& \mathrm{C}_{\mathrm{it}}=\alpha_{0}+\alpha_{1} \operatorname{prov}_{\mathrm{i}} \times \text { peri }_{\mathrm{t}} \times \text { if_econ }_{\mathrm{j}}+\alpha_{2} \operatorname{prov}_{\mathrm{i}} \times \text { peri }_{\mathrm{t}}+\alpha_{3} \text { prov }_{\mathrm{i}} \times \text { if_econ }_{\mathrm{j}} \\
& +\alpha_{4} \text { peri }_{t} \times \text { if_econ }_{j}+\alpha_{5} \text { control }_{i t}+\eta_{i}+\gamma_{t}+\mu_{\text {it }} \\
& \mathrm{C}_{\mathrm{it}}=\alpha_{0}+\alpha_{1} \text { prov }_{\mathrm{i}} \times \text { peri }_{\mathrm{t}} \times{\text { if } \_i n d u_{j}}_{\mathrm{j}}+\alpha_{2} \text { prov }_{\mathrm{i}} \times \text { peri }_{\mathrm{t}}+\alpha_{3} \text { prov }_{\mathrm{i}} \times{\text { if } \_i n d u_{j}} \\
& +\alpha_{4} \text { peri }_{t} \times \text { if_indu }{ }_{j}+\alpha_{5} \text { control }_{i j}+\eta_{i}+\gamma_{t}+\mu_{i t} \\
& \mathrm{C}_{\mathrm{it}}=\alpha_{0}+\alpha_{1} \text { prov }_{\mathrm{i}} \times \text { peri }_{\mathrm{t}} \times \text { if_cons }_{\mathrm{j}}+\alpha_{2} \text { prov }_{\mathrm{i}} \times \text { peri }_{\mathrm{t}}+\alpha_{3} \text { prov }_{\mathrm{i}} \times \text { if_cons }_{\mathrm{j}} \\
& +\alpha_{4} \text { peri }_{\mathrm{t}} \times \text { if_cons }_{\mathrm{j}}+\alpha_{5} \text { control }_{\mathrm{ij}}+\eta_{\mathrm{i}}+\gamma_{\mathrm{t}}+\mu_{\mathrm{it}} \\
& \mathrm{C}_{\mathrm{it}}=\alpha_{0}+\alpha_{1} \text { prov }_{\mathrm{i}} \times \text { peri }_{\mathrm{t}} \times \text { if_serv }_{\mathbf{j}}+\alpha_{2} \operatorname{prov}_{\mathrm{i}} \times \text { peri }_{\mathrm{t}}+\alpha_{3} \operatorname{prov}_{\mathrm{i}} \times \text { if_serv }_{\mathbf{j}} \\
& +\alpha_{4} \text { peri }_{\mathrm{t}} \times \text { if_serv }_{\mathrm{j}}+\alpha_{5} \text { control }_{\mathrm{ij}}+\eta_{\mathrm{i}}+\gamma_{\mathrm{t}}+\mu_{\mathrm{it}} \\
& \mathrm{Y}_{\mathrm{it}}=\beta_{0}+\beta_{1} \text { prov }_{\mathrm{i}} \times \text { peri }_{\mathrm{t}} \times \text { if_econ }_{\mathrm{j}}+\beta_{2} \text { prov }_{\mathrm{i}} \times \text { peri }_{\mathrm{t}}+\beta_{3} \text { prov }_{\mathrm{i}} \times \text { if_econ }_{\mathrm{j}} \\
& +\beta_{4} \text { peri }_{\mathrm{t}} \times \text { if_econ }_{\mathrm{j}}+\beta_{5} \text { control }_{\mathrm{it}}+\eta_{\mathrm{i}}+\gamma_{\mathrm{t}}+\mu_{\mathrm{it}}
\end{aligned}
$$

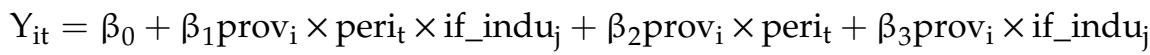

$$
\begin{aligned}
& +\beta_{4} \text { peri }_{t} \times \text { if_indu }{ }_{j}+\beta_{5} \text { control }_{i j}+\eta_{i}+\gamma_{t}+\mu_{i t} \\
& \mathrm{Y}_{\mathrm{it}}=\beta_{0}+\beta_{1} \text { prov }_{\mathrm{i}} \times \text { peri }_{\mathrm{t}} \times \text { if_cons }_{\mathrm{j}}+\beta_{2} \text { prov }_{\mathrm{i}} \times \text { peri }_{\mathrm{t}}+\beta_{3} \text { prov }_{\mathrm{i}} \times \text { if }_{-} \text {cons }_{\mathrm{j}} \\
& +\beta_{4} \text { peri }_{t} \times \text { if }_{-} \text {cons }_{j}+\beta_{5} \text { control }_{i j}+\eta_{i}+\gamma_{t}+\mu_{i t} \\
& \mathrm{Y}_{\mathrm{it}}=\beta_{0}+\beta_{1} \text { prov }_{\mathrm{i}} \times \text { peri }_{\mathrm{t}} \times \text { if_serv }_{\mathrm{j}}+\beta_{2} \operatorname{prov}_{\mathrm{i}} \times \text { peri }_{\mathrm{t}}+\beta_{3} \operatorname{prov}_{\mathrm{i}} \times \text { if_serv }_{\mathrm{i}} \\
& +\beta_{4} \text { peri }_{\mathrm{t}} \times \text { if_serv }_{\mathrm{j}}+\beta_{5} \text { control }_{\mathrm{ij}}+\eta_{\mathrm{i}}+\gamma_{\mathrm{t}}+\mu_{\mathrm{it}}
\end{aligned}
$$

here, if_econ is the dummy variable of the economic development differences, and if_indu, if_cons, and if_serv are the dummy variables of the industrial, construction, and service development differences, respectively (classified according to the categories of the industries that are involved in carbon trading in the pilot provinces and cities, as shown in Appendix A). The economic growth level and industry development levels are characterized by per capita GDP, per capita industrial added value, per capita construction added value, and per capita service added value, respectively. If above indicators of the province $\mathrm{j}$ ranks at the top $50 \%$ of the China, corresponding dummy variables if_econ, if_indu, if_cons, and if_serv are set to 1 , the other provinces are set to 0 . The remaining variables are defined as in Equations (1) and (2). In the above equations, we are also concerned with the coefficient of the triple cross term. In this paper, the DDD model is based on the DID model and adds the dummy variables of economic development level difference and industrial development level difference, in order to further analyze whether the development level difference will affect the impact of ETS. Through the significance of the double cross term $Z$, we can initially determine whether the DID satisfies the common trend hypothesis and the necessity of DDD analysis.

\subsection{Data and Variable}

The calculation of carbon emissions includes two parts: fossil energy and electricity. The original provincial data of 2005-2017 are from the China Energy Statistical Yearbook (2006-2018). The standard coal coefficient, carbon emissions coefficient and average $\mathrm{CO} 2$ emissions factor of the regional power grid are derived from the IPCC guidelines for national greenhouse gas inventories and the general 
principles for computing comprehensive energy consumption (GB/T2589-2008). The control variables for evaluating carbon emission effect include population factors, economic factors, technological factors, environmental regulations, and innovation driving factors. Here, population size and the urbanization rate are population factors, per capita GDP and the industrialization rate are economic factors, the carbon intensity and the energy structure are technological factors, the intensity of the environmental pollution control is an environmental regulation factor, and the research structure and research intensity are innovation driving factors. The selected control variables for GDP are the capital stock, the labor force, and energy consumption. Environmental effect indicators and economic effect indicators constitute an indicator system for testing the "Porter effect" of China's carbon trading pilot. The original data of population size, urbanization rate, per capita GDP, industrialization rate, capital stock, and labor force are obtained from the China Statistical Yearbook (2006-2018). The original data of carbon intensity, energy structure and energy consumption are obtained from China Energy Statistical Yearbook (2006-2018). The intensity of environmental pollution control, research structure and research intensity are obtained from the China Environmental Yearbook (2006-2018) and the China Scientific and the Statistical Yearbook (2006-2018). The specific meaning and calculation method of each index are shown in Table 1 below.

Table 1. Observable variables and calculation method.

\begin{tabular}{|c|c|c|}
\hline Variable Name & Variable Meaning (Unit) & Calculation Method \\
\hline $\operatorname{lnc}$ & carbon_emission (ten thousand tons) & logarithm of $\mathrm{CO}_{2}$ emission \\
\hline $\ln p$ & People (ten thousand people) & $\begin{array}{c}\text { Logarithm of POP at the end of the } \\
\text { year }\end{array}$ \\
\hline us & urbanization_structure (\%) & Urban POP/total POP \\
\hline a & $\begin{array}{c}\text { average_gdp (RMB ten thousand } \\
\text { yuan/person) }\end{array}$ & GDP/total POP \\
\hline is & industrilization_structure $(\%)$ & Industrial value added/GDP \\
\hline ci & $\begin{array}{l}\text { carbon_emission_intensity (ten thousand } \\
\text { tons/RMB100 million yuan) }\end{array}$ & $\mathrm{CO}_{2}$ emission/GDP \\
\hline energs & energy_structure $(\%)$ & Coal consumption/fossil energy \\
\hline environs & environment_structure (\%) & Environmental investment/GDP \\
\hline rs & research_structure (\%) & R\&D personnel/total POP \\
\hline ri & research_intensity $(\%)$ & R\&D expenditure/GDP \\
\hline $\operatorname{lngdp}$ & $\begin{array}{c}\text { gross_domestic_production (RMB100 } \\
\text { million yuan) }\end{array}$ & Logarithm of GDP \\
\hline $\operatorname{lnk}$ & Capital (RMB100 million yuan) & Logarithm of capital stock \\
\hline $\ln l$ & Labour (ten thousand people) & Logarithm of employment \\
\hline lne & $\begin{array}{l}\text { energy_consumption (ten thousand tons } \\
\text { standard coal) }\end{array}$ & Logarithm of energy consumption \\
\hline
\end{tabular}

1 GDP converted into constant price in 2005. 2 Capital stock is deducted according to annual depreciation rate in the base period of 2005.

\section{Empirical Results}

\subsection{Descriptive Statistics and Comparison of Variables}

Table 2 shows that the mean and standard error of each variable are within reasonable ranges, and the existence of extreme outliers can basically be excluded; thus, the data stability is good. Table 3 shows that before the implementation of the policy, the carbon emissions of the pilot provinces were larger than those of the non-pilot provinces, but after the implementation of the policy, the carbon emissions of the non-pilot provinces were larger than those of the pilot provinces. This initially indicates that the ETS pilot policy may generate emissions reductions. After the implementation of the policy, the GDP gap between the pilot and non-pilot provinces has increased slightly. It seems that the policy promotes economic development and achieves the "Porter hypothesis." In addition, it is found that before the implementation of the policy, there are differences in the indicators of the pilot provinces and 
non-pilot provinces, such as the urbanization rate, per capita GDP, carbon intensity, energy structure, research structure and research intensity; thus, it was found that the performances of the pilot provinces are better than those of the non-pilot provinces. Therefore, the differences may not simply a matter of policy.

Table 2. Descriptive statistics table.

\begin{tabular}{cccccc}
\hline Variable & Obs & Mean & Std. & Min & Max \\
\hline lnc & 390 & 10.26 & 0.83 & 7.58 & 12.35 \\
lnp & 390 & 3.55 & 0.32 & 2.73 & 4.05 \\
us & 390 & 52.96 & 13.96 & 26.87 & 89.60 \\
a & 390 & 2.82 & 1.76 & 0.54 & 10.89 \\
is & 390 & 46.40 & 8.03 & 19.00 & 59.05 \\
ci & 390 & 3.87 & 2.47 & 1.47 & 18.26 \\
energs & 390 & 72.01 & 14.65 & 11.15 & 94.33 \\
environs & 390 & 1.36 & 0.67 & 0.30 & 4.24 \\
rs & 390 & 0.23 & 0.24 & 0.01 & 1.24 \\
ri & 390 & 1.42 & 1.05 & 0.18 & 6.01 \\
lngdp & 390 & 9.05 & 0.95 & 6.30 & 11.07 \\
lnk & 390 & 10.08 & 0.92 & 7.39 & 12.04 \\
lnl & 390 & 7.60 & 0.81 & 5.67 & 8.83 \\
lne & 390 & 10.26 & 0.83 & 7.58 & 12.35 \\
\hline
\end{tabular}

Due to the availability of data, Shenzhen is included in the statistics of Guangdong Province.

Table 3. Comparison of variables before and after implementation of the policy.

\begin{tabular}{ccccc}
\hline \multirow{2}{*}{ Variable } & \multicolumn{2}{c}{ Before Pilot Policy (2005-2013) } & \multicolumn{2}{c}{ After Pilot Policy (2014-2017) } \\
\cline { 2 - 5 } & Un-Pilot Province & Pilot Province & Un-Pilot Province & Pilot Province \\
\hline lnc & 9.98 & 10.03 & 10.88 & 10.73 \\
$\ln$ & 3.56 & 3.48 & 3.57 & 3.53 \\
us & 45.91 & 69.50 & 54.20 & 74.26 \\
a & 2.17 & 4.35 & 3.04 & 5.79 \\
is & 48.80 & 44.51 & 44.06 & 38.50 \\
ci & 3.69 & 2.15 & 5.57 & 2.60 \\
energs & 77.20 & 66.40 & 52.33 & 37.11 \\
environs & 1.35 & 1.26 & 1.49 & 1.10 \\
rs & 0.13 & 0.44 & 0.20 & 0.60 \\
ri & 0.99 & 9.45 & 9.31 & 3.06 \\
lngdp & 8.78 & 9.29 & 10.67 & 9.90 \\
lnk & 9.73 & 10.09 & 7.70 & 10.88 \\
lnl & 7.60 & 7.43 & 10.88 & 7.59 \\
lne & 9.98 & 10.03 & & 10.73 \\
\hline
\end{tabular}

\subsection{Estimation of PSM Method}

In Table 4, $\mathrm{m} 1-\mathrm{m} 6$ respectively represent the five nearest neighbors caliper matching (caliper radius 0.01 ), the one nearest neighbor caliper matching (caliper radius 0.01 ), caliper radius matching (caliper radius 0.01), caliper radius matching (caliper radius 0.05), kernel matching (quadratic kernel), and kernel matching (Gaussian kernel). From the |bias| values of the six matching methods, we can see that the biases of the other control variables except population and energy consumption are significantly reduced after matching, which indicate that the PSM has indeed significantly improved the data error rate. The criterion for the success of matching is whether each variable passes the balance test after matching, that is, whether the $p$ value of the $t$ test after matching is significant or not. After all matching methods, the $p>|t|$ value of each variable in the table below is not significant (more than $10 \%)$. That is, the original hypothesis is rejected, indicating that there is no systematic difference in the 
data before and after matching; therefore, the carbon trading pilot policy can be considered to be a random allocation experiment.

Table 4. Propensity score matching (PSM) estimation.

\begin{tabular}{|c|c|c|c|c|c|c|c|c|c|c|c|c|c|}
\hline \multirow{2}{*}{\multicolumn{2}{|c|}{ Variable }} & \multicolumn{2}{|c|}{ m1 } & \multicolumn{2}{|c|}{$\mathrm{m} 2$} & \multicolumn{2}{|c|}{$\mathrm{m} 3$} & \multicolumn{2}{|c|}{$\mathrm{m} 4$} & \multicolumn{2}{|c|}{ m5 } & \multicolumn{2}{|c|}{$\mathrm{m} 6$} \\
\hline & & \multirow{2}{*}{ |bias| } & \multirow{2}{*}{$\frac{\mathbf{p}>|\mathbf{t}|}{0.13}$} & \multirow{2}{*}{ |bias| } & \multirow{2}{*}{$\frac{\mathbf{p}>|\mathbf{t}|}{0.13}$} & \multirow{2}{*}{ |bias| } & \multirow{2}{*}{$\frac{\mathbf{p}>|\mathbf{t}|}{0.13}$} & \multirow{2}{*}{ |bias| } & \multirow{2}{*}{$\frac{\mathbf{p}>|\mathbf{t}|}{0.13}$} & \multirow[t]{2}{*}{ |bias| } & \multirow{2}{*}{$\frac{\mathbf{p}>|\mathbf{t}|}{0.13}$} & \multirow[t]{2}{*}{ |bias| } & \multirow{2}{*}{$\begin{array}{c}\mathbf{p}>|\mathbf{t}| \\
0.13\end{array}$} \\
\hline $\ln p$ & $\mathrm{U}$ & & & & & & & & & & & & \\
\hline & M & -52.60 & 0.45 & 1.70 & 0.64 & -52.60 & 0.45 & -5.90 & 0.46 & -11.80 & 0.44 & 78.10 & 0.90 \\
\hline \multirow[t]{2}{*}{ us } & U & & 0 & & 0 & & 0 & & 0 & & 0 & & 0 \\
\hline & M & 62.80 & 0.17 & 58.10 & 0.12 & 62.80 & 0.17 & 92.80 & 0.77 & 91.70 & 0.73 & 86.70 & 0.50 \\
\hline \multirow[t]{2}{*}{ a } & $\mathrm{U}$ & & 0 & & 0 & & 0 & & 0 & & 0 & & 0 \\
\hline & M & 37.40 & 0.11 & 36.70 & 0.19 & 37.40 & 0.11 & 95.70 & 0.93 & 93.70 & 0.90 & 89.60 & 0.80 \\
\hline \multirow[t]{2}{*}{ is } & U & & 0 & & 0 & & 0 & & 0 & & 0 & & 0 \\
\hline & M & 76.70 & 0.62 & 85.20 & 0.76 & 76.70 & 0.62 & 26.60 & 0.17 & 26.50 & 0.17 & 86.90 & 0.83 \\
\hline \multirow[t]{2}{*}{$\mathrm{ci}$} & $\mathrm{U}$ & & 0 & & 0 & & 0 & & 0 & & 0 & & 0 \\
\hline & M & 96.30 & 0.82 & 91.40 & 0.63 & 96.30 & 0.82 & 98.60 & 0.93 & 97.60 & 0.88 & 98.70 & 0.92 \\
\hline \multirow[t]{2}{*}{ energs } & $\mathrm{U}$ & & 0 & & 0 & & 0 & & 0 & & 0 & & 0 \\
\hline & M & 87.20 & 0.57 & 81.80 & 0.38 & 87.20 & 0.57 & 48.70 & 0.26 & 49.30 & 0.26 & 81.70 & 0.65 \\
\hline \multirow[t]{2}{*}{ environs } & $\mathrm{U}$ & & 0.06 & & 0.06 & & 0.06 & & 0.06 & & 0.06 & & 0.06 \\
\hline & M & 84.70 & 0.90 & 91.50 & 0.94 & 84.70 & 0.90 & 43.20 & 0.49 & 45.70 & 0.51 & 25.60 & 0.36 \\
\hline \multirow[t]{2}{*}{ rs } & U & & 0 & & 0 & & 0 & & 0 & & 0 & & 0 \\
\hline & M & 91.00 & 0.70 & 90.20 & 0.68 & 91.00 & 0.70 & 96.90 & 0.88 & 97.40 & 0.89 & 98.00 & 0.91 \\
\hline \multirow[t]{2}{*}{ ri } & $\mathrm{U}$ & & 0 & & 0 & & 0 & & 0 & & 0 & & 0 \\
\hline & M & 68.40 & 0.16 & 70.90 & 0.20 & 68.40 & 0.16 & 92.60 & 0.75 & 92.30 & 0.74 & 98.90 & 0.96 \\
\hline \multirow[t]{2}{*}{$\operatorname{lnk}$} & $\mathrm{U}$ & & 0.01 & & 0.01 & & 0.01 & & 0.01 & & 0.01 & & 0.01 \\
\hline & M & 89.7 & 0.83 & 29.90 & 0.15 & 82.90 & 0.72 & 74.50 & 0.50 & 74.90 & 0.50 & 32.20 & 0.06 \\
\hline \multirow[t]{2}{*}{$\operatorname{lnl}$} & U & & 0.14 & & 0.14 & & 0.14 & & 0.14 & & 0.14 & & 0.14 \\
\hline & M & 94.5 & 0.96 & -8.10 & 0.26 & 86.50 & 0.89 & 26.30 & 0.35 & 27.00 & 0.36 & -31.00 & 0.09 \\
\hline $\operatorname{lne}$ & U & & 1.00 & & 1.00 & & 1.00 & & 1.00 & & 1.00 & & 1.00 \\
\hline & M & -7.8 & 0.75 & -7.31 & 0.79 & -3.50 & 0.84 & -5.22 & 0.81 & -2.59 & 0.91 & -2.68 & 0.91 \\
\hline
\end{tabular}

\section{3. "Porter Effect" of ETS Pilot Policy}

Based on the DID model in and Equations (1) and (2), we evaluate the effects of the ETS pilot policy on carbon emissions and GDP. In Table 5, $\mathrm{m} 1$ indicates adding the provincial and time-fixed effect model without control variables. The results show that the interaction term is negative, but the coefficient is not significant. After adding the control variables, the $\mathrm{m} 2$ interaction term's coefficient is significant, and the $\mathrm{R}$ squared is significantly increased from 0.235 to 0.946 , which indicate that the initial carbon trading pilot policy mechanism is not sufficiently perfect and that it is vulnerable to other policies. Therefore, it is necessary to introduce important control variables to make the results more robust. $\mathrm{m} 2$ shows that the policy can reduce carbon emissions by $10.0 \%$. The analysis of the control variables shows that the coefficients of some of the control variables are significant. Population, carbon intensity, and per capita GDP have significant positive effects on carbon emissions; and the environmental pollution control intensity, research structure, and research intensity have negative effects.

The following analyzes the economic effects of the policy. $\mathrm{m} 3$ shows that the interaction coefficient without the control variables is not significant, and $\mathrm{m} 4$ shows that the overall result is significantly positive after adding the control variables. The $\mathrm{R}$ squared increases from 0.532 to 0.957 , indicating that the ETS pilot policy can achieve economic effects. Among the variables, the capital stock, employment, and energy consumption factors all have significant positive effects. This study concludes that the ETS pilot policy can achieve the "Porter effect," which is basically consistent with [14,40-42]. Dong et al. argued that the policy cannot achieve the "Porter effect" in the short term because the economic effect is not significant [16], which is possibly due to starting the experiment in different years and the different calculation methods of the control variables. 
Table 5. Difference in differences (DID) estimation.

\begin{tabular}{|c|c|c|c|c|}
\hline & \multicolumn{2}{|c|}{$\ln c$} & \multicolumn{2}{|c|}{ lngdp } \\
\hline & m1 & $\mathrm{m} 2$ & m3 & $\mathrm{m} 4$ \\
\hline $\mathrm{Z}$ & $-0.101(-1.21)$ & $-0.100 *(-1.80)$ & $0.081(1.24)$ & $0.064 *(1.85)$ \\
\hline $\ln p$ & & $2.393 * * *(53.55)$ & & \\
\hline us & & $0.019^{* * *}(9.22)$ & & \\
\hline $\mathrm{a}$ & & $0.165^{* * *}(9.54)$ & & \\
\hline is & & $0.013^{* * *}(8.43)$ & & \\
\hline $\mathrm{ci}$ & & $0.172 * * *(9.54)$ & & \\
\hline energs & & $0.007^{* * *}(6.80)$ & & \\
\hline environs & & $-0.072 * * *(-2.75)$ & & \\
\hline rs & & $-0.138 *(-1.81)$ & & \\
\hline ri & & $-0.096^{* * *}(-4.74)$ & & \\
\hline $\operatorname{lnk}$ & & & & $0.618^{* * *}(20.96)$ \\
\hline $\operatorname{lnl}$ & & & & $0.344^{* * *}(16.08)$ \\
\hline lne & & & & $0.214^{* * *}(8.29)$ \\
\hline control & no & yes & no & yes \\
\hline province & yes & yes & yes & yes \\
\hline period & yes & yes & yes & yes \\
\hline R-square & 0.235 & 0.946 & 0.532 & 0.957 \\
\hline
\end{tabular}

\subsection{Dynamic Effect Test and Placebo Test}

The precondition of the consistency of the DID estimation result is that the treatment group and the control group conform to the hypothesis of parallel trends. That is, without policy intervention, the development trends of the outcome variables in the treatment group and the control group are consistent. In Table 6, if_2010-if_2017 in the dynamic effect model represent that the initial years of the policy implementation are set as 2010-2017, and $\mathrm{m} 1$ and $\mathrm{m} 2$ represent the emissions reduction effect and economic effect, respectively. It is found that the interaction coefficients of 2010-2013 (the years before the policy implementation) are not significant, and the coefficients of 2014-2017 (the years after the policy implementation) are all significant at the $10 \%$ level or better. The analysis shows that the coefficients of the emissions reduction effect in 2014-2017 are greater than those in 2010-2013 and much closer to the DID estimation $(-10.0 \%)$, and the coefficients of the economic effect in 2014-2017 are stable between $6.1 \%$ and $6.9 \%$. It also shows that the ETS pilot policy is achieving a win-win situation between the emissions reduction effect and the economic effect without a hysteresis effect or decreasing effectiveness in the pilots.

To further verify the robustness of the results, a regional placebo test was conducted. That is, we assume that the other regions with similar geographical locations and development levels have actually implemented the policy, and the policy implementation time remains unchanged. If the empirical results show that the hypothetical regions can also achieve the policy effect, it cannot be considered that the policy effect of the pilot regions is due to the policy, and, vice versa, it indicates that the policy is robust. This study takes reference of the Zhou et al. method on the control group selection for the regional placebo test [15]. Thus, it was found that the provinces with higher economic growth rates, stronger environmental regulations, and higher research capabilities are more likely to be selected for the ETS pilot. Taking Shandong, Jiangsu, Anhui, Zhejiang, and Fujian provinces as the hypothetical treatment group, the initial year of the policy implementation remains unchanged. m3-m6 represent the results of the emission reduction effect without control variables, the emission reduction effect with control variables, the economic effect without control variables, and the economic effect with control variables, respectively. It is found that the Z.district, which represents the interaction coefficient of the emissions reduction effect is positive, while the Z.district of the economic effect is not statistically significant, thus proving the robustness of the previous DID estimation. 
Table 6. Dynamic effect test and placebo test.

\begin{tabular}{|c|c|c|c|c|c|c|}
\hline & \multicolumn{2}{|c|}{ Dynamic Effect } & \multicolumn{4}{|c|}{ Regional Placebo Test } \\
\hline & m1 & $\mathrm{m} 2$ & m3 & $\mathrm{m} 4$ & m5 & m6 \\
\hline Z & $-0.100 *(1.80)$ & $0.064 *(1.85)$ & & & & \\
\hline Z.if_2010 & $-0.052(-0.68)$ & $0.071^{* *}(2.44)$ & & & & \\
\hline Z.if_2011 & $-0.065(-1.17)$ & 0.048 (1.64) & & & & \\
\hline Z.if_2012 & $-0.087(-1.53)$ & 0.108 (1.66) & & & & \\
\hline Z.if_2013 & $-0.092(-1.64)$ & 0.077 (1.07) & & & & \\
\hline Z.if_2014 & $-0.107^{*}(-1.91)$ & $0.061 * *(2.31)$ & & & & \\
\hline Z.if_2015 & $-0.097 *(-1.86)$ & $0.069 *(1.94)$ & & & & \\
\hline Z.if_2016 & $-0.092 *(-1.96)$ & $0.062 *(1.82)$ & & & & \\
\hline Z.if_2017 & $-0.101 *(-1.90)$ & $0.063 *(1.90)$ & & & & \\
\hline Z.district & & & $0.051(0.30)$ & $0.057(1.24)$ & $0.039(0.23)$ & $\begin{array}{c}0.051 \\
(1.44)\end{array}$ \\
\hline control & yes & yes & no & yes & no & yes \\
\hline province & no & no & yes & yes & yes & yes \\
\hline time & no & no & yes & yes & yes & yes \\
\hline R-square & 0.832 & 0.904 & 0.351 & 0.942 & 0.238 & 0.944 \\
\hline
\end{tabular}

\subsection{Heterogeneity Impact on Policy Effect}

The PSM-DID estimation shows that China's ETS pilot policy has indeed achieved an ideal "Porter effect." However, for the national ETS that is being gradually established, the impact of interprovincial differences on economic development and industrial development and their impacts on the final effect of the policy are bound to be a major problem. Based on the PSM-DID results, this study constructs a DDD model by introducing dummy variables for the economic development differences and industrial development differences and also studies the mechanism of the effect of heterogeneity of economic and industrial differences on the policy.

\subsubsection{Economic Development Differences}

According to Equations (3) and (5), it can be found from Table 7 that the interaction coefficients of model $\mathrm{m} 1$ without the control variables according to the DID and DDD estimations are not significant. The DDD estimation is -0.209 , which indicates that the ETS policy may have a lower emissions effect on the provinces with higher economic development rates than the provinces with lower economic development rates. Thus, the pilot policy strongly inhibits the carbon emissions effect in the provinces with higher economic development rates. The R-squared in model $\mathrm{m} 2$ with control variables increases significantly from 0.520 to 0.957 , and except for the research structure, the coefficients of the other eight control variables are significant and have better statistical significance. The economic significance analysis is as follows. (1) The $\mathrm{p}$ value of the DID interaction term $\mathrm{Z}$ passes the $\mathrm{t}$ test at the $10 \%$ significance level. Thus, we can conclude that there may be time trend differences between the control group and treatment group, and the results of the DDD method are more robust than those of the DID method. (2) The coefficient of the DDD interaction term $Z^{*}$ if_econ is significant $(-0.370)$, indicating that the ETS pilot policy has strong carbon emission inhibitory effects on the provinces with higher economic development rates than the provinces with lower economic development rates. (3) The mechanism effect, population, per capita GDP and emissions intensity have major positive effects on carbon emissions. The environmental pollution control intensity and research intensity have negative effects on carbon emissions (the industrialization rate, the proportion of coal consumption, and the urbanization rate also have positive effects). The results of models $\mathrm{m} 3$ and $\mathrm{m} 4$ studying the economic effect show that the coefficient of the interaction term of the DDD estimation is small and the P-value is not significant, regardless of whether or not control variables are included, indicating that the level of economic development has no significant effect on the economic effect of the policy. Compared with the results of this study and the related literature [7,34], we can find that the ETS policy has a more significant effect on promoting the development of regions and enterprises with higher development 
levels since these entities are better than the regions and enterprises with lower development levels in terms of investment intensity and environmental regulation investments, thus achieving better "environmental welfare" and "economic welfare."

Table 7. Policy effect of economic development differences.

\begin{tabular}{|c|c|c|c|c|}
\hline & \multicolumn{2}{|c|}{$\operatorname{lnc}$} & \multicolumn{2}{|c|}{ lngdp } \\
\hline & m1 & $\mathrm{m} 2$ & m3 & $\mathrm{m} 4$ \\
\hline Z*if_econ & $-0.209(-0.71)$ & $-0.370^{* * *}(-3.96)$ & $0.001(0.59)$ & $0.007(0.87)$ \\
\hline Z & $-0.044(-0.20)$ & $0.089 *(1.85)$ & $0.013(1.03)$ & $-0.052 *(-1.77)$ \\
\hline $\ln p$ & & $2.248^{* * *}(43.73)$ & & \\
\hline us & & $0.010^{* * *}(4.41)$ & & \\
\hline $\mathrm{a}$ & & $0.176^{* * *}(10.55)$ & & \\
\hline is & & $0.012 * * *(7.77)$ & & \\
\hline ci & & $0.167 * * *(9.90)$ & & \\
\hline energs & & $0.008^{* * *}(8.01)$ & & \\
\hline environs & & $-0.053^{* *}(-2.34)$ & & \\
\hline rs & & $-0.048(-0.78)$ & & \\
\hline ri & & $-0.032 *(-1.84)$ & & \\
\hline $\operatorname{lnk}$ & & & & $0.565^{* * *}(23.03)$ \\
\hline $\ln 1$ & & & & $0.523^{* * *}(30.57)$ \\
\hline lne & & & & $-0.023(-1.53)$ \\
\hline control & no & yes & no & yes \\
\hline province & yes & yes & yes & yes \\
\hline time & yes & yes & yes & yes \\
\hline R-square & 0.520 & 0.957 & 0.568 & 0.981 \\
\hline
\end{tabular}

\subsubsection{Industrial Development Differences}

By introducing the dummy variables of the industrial development differences, we study whether there is heterogeneity in the policy effect of the ETS pilot project in provinces with different industries. These industries are divided into industry, service and construction according to the seven ETS pilots (see Appendix A for the details). According to Equations (4a-4c), as shown in Table 8, the DID and DDD interaction term coefficients of models $\mathrm{m} 1, \mathrm{~m} 3$, and $\mathrm{m} 5$ without the control variables are not significant. The interaction coefficients of models $\mathrm{m} 2, \mathrm{~m} 4$, and $\mathrm{m} 6$ with the control variables are significant, and the R-squared significantly increases to $95 \%$. Due to the length limitations of this paper, in the following, we mainly focus on the results of models $\mathrm{m} 2$, m4, and m6. From a statistical perspective, the coefficients of the control variables for these three models are significant with better statistical significance. The economic significance analysis is as follows. (1) The $Z$ value and the DID interaction coefficients of models $\mathrm{m} 2, \mathrm{~m} 4$, and $\mathrm{m} 6$ all pass the $\mathrm{t}$-test at the $10 \%$ level or better, thus indicating that there may exist time trend differences between the control group and the treatment group. Therefore, the DDD estimation provides more robust results than the DID estimation. (2) The coefficients of $Z^{*}$ if_are $0.058,-0.488$, and 0.081 , respectively, which indicate that the policy has a weaker inhibitory effect on the carbon emissions of provinces with higher levels of industrial and construction development compared with the provinces with lower levels of industrial and construction development. Furthermore, the policy has a stronger inhibitory effect on the carbon emissions in the provinces with higher levels of service development compared with the provinces with lower levels of service development. (3) From the perspective of the mechanism's effect, the population size, emissions intensity, and per capita GDP factors have major positive effects on carbon emissions; the environmental pollution control intensity, research structure, and research intensity have negative effects on carbon emissions (the urbanization rate, industrialization, and proportion of coal consumption proportion have positive economic effects). 
From Table 9 (Equations (6a)-(6c)), we can see that although the coefficients of lnk, lnl, and lne are significant, the interaction coefficients in the DDD estimation of $Z^{*}$ if showing that the level of industrial development has no significant impact on the economic effect of the policy. By comparing the results for the economic development differences and the industrial development differences, we can see that the policy has a stronger inhibitory effect on the carbon emissions in provinces with higher levels of economic and service development, and the level of the service industry's development is often the most important indicator of economic development, indicating the rationality and practical significance of the empirical results in this study.

Table 8. Emission reduction effect of industrial development differences.

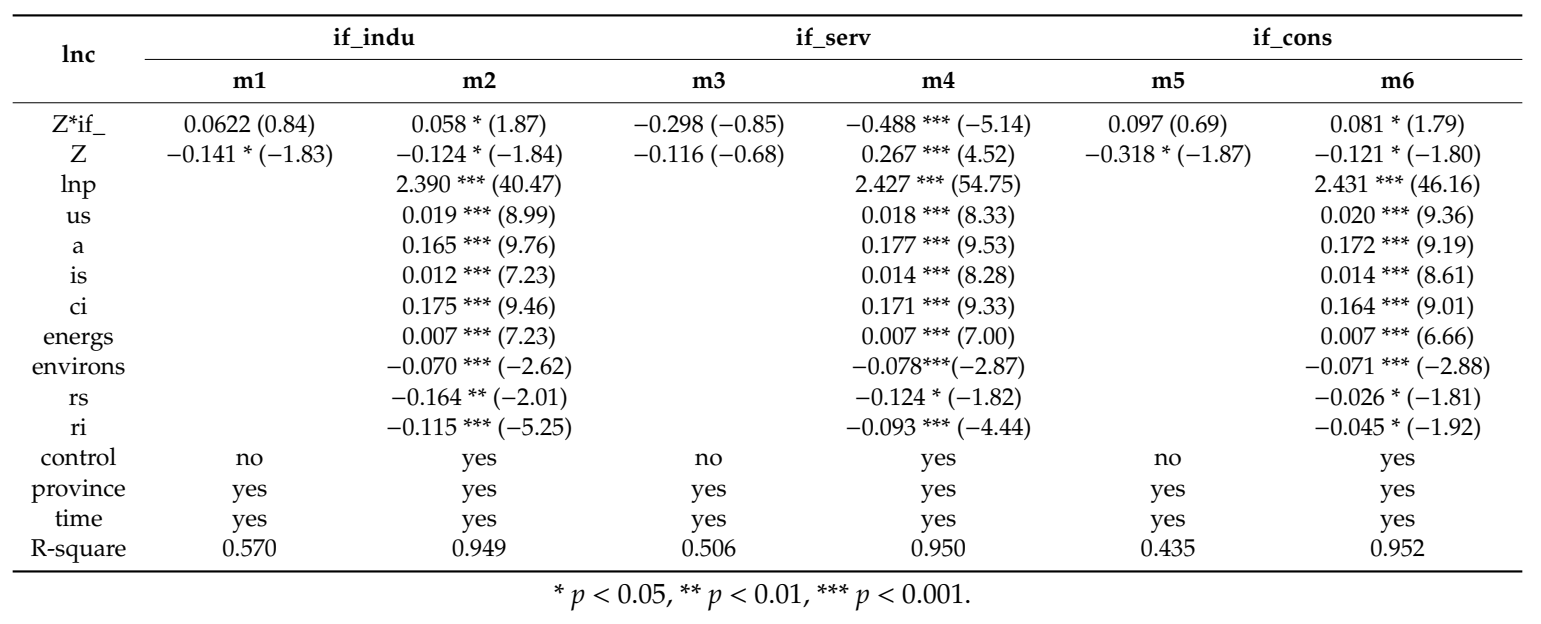

Table 9. Economic effect of industrial development differences.

\begin{tabular}{|c|c|c|c|c|c|c|}
\hline \multirow{2}{*}{$\operatorname{lngdp}$} & \multicolumn{2}{|c|}{ if_indu } & \multicolumn{2}{|c|}{ if_serv } & \multicolumn{2}{|c|}{ if_cons } \\
\hline & m1 & $\mathrm{m} 2$ & m3 & $\mathrm{m} 4$ & m5 & m6 \\
\hline$Z^{*}$ if__ & $-0.020(-0.20)$ & $-0.033(-0.21)$ & $-0.019(-0.18)$ & $-0.027(-0.28)$ & $-0.150(-0.48)$ & $-0.169(-1.27)$ \\
\hline $\operatorname{lnk}$ & & $0.602^{* * *}(21.26)$ & & $0.594^{* * *}(21.19)$ & & $0.534^{* * *}(19.54)$ \\
\hline $\operatorname{lnl}$ & & $0.337^{* * *}(14.48)$ & & $0.315^{* * *}(13.61)$ & & $0.381^{* * *}(15.90)$ \\
\hline lne & & $0.209^{* * *}(8.47)$ & & $0.188^{* * *}(7.81)$ & & $0.275^{* * *}(11.08)$ \\
\hline time & yes & yes & yes & yes & yes & yes \\
\hline R-square & 0.532 & 0.962 & 0.568 & 0.967 & 0.451 & 0.967 \\
\hline
\end{tabular}

\subsubsection{DDD Mechanism Test}

By successively using each control variable as an explanatory variable, we study the conduction mechanism of the economic differences and industrial differences on the carbon reduction effect and economic effect. According to the analysis in Table 10, the following is found. (1) From the coefficients of the Z-values, it is found that the causes of the carbon reduction effect in the ETS pilot provinces are mainly from the reductions of the industrialization rate, carbon intensity, and energy structure and the increases of the research structure and research intensity. Furthermore, the economic effect in the ETS pilot provinces is due to the increased capital, employment and energy consumption. (2) According to the coefficients of $Z^{*}$ if_econ, $Z^{*}$ if_indu, $Z^{*}$ if_serv, and $Z^{*}$ if_cons, compared with the provinces with lower levels of economic and industrial development, the population size, carbon intensity and per capita GDP have positive effects on the carbon emissions in the provinces with higher levels of these variables. Further, the intensity of the environmental pollution controls, research structure and research intensity have negative effects on carbon emissions in the provinces with higher levels of 
economic and industrial development. The levels of economic and industrial development have no significant economic effect on the policy implementation (due to this paper's length limitations, the table is not reported).

Table 10. Mechanism effect on carbon emission trading system (ETS) pilot policy.

\begin{tabular}{|c|c|c|c|c|c|c|c|c|c|c|c|c|}
\hline & $\ln p$ & us & a & is & ci & energs & environs & rs & ri & $\ln k$ & $\ln 1$ & lne \\
\hline Z*if_econ & $\begin{array}{c}0.137^{* *} \\
(1.95)\end{array}$ & $\begin{array}{l}1.299 \\
(0.63)\end{array}$ & $\begin{array}{c}0.666^{* *} \\
(1.93)\end{array}$ & $\begin{array}{l}0.961 \text { * } \\
(1.86)\end{array}$ & $\begin{array}{l}0.719 \\
(0.43)\end{array}$ & $\begin{array}{l}0.181 \\
(0.78)\end{array}$ & $\begin{array}{c}-0.050 \\
*(-1.82)\end{array}$ & $\begin{array}{c}-0.165 * \\
(1.84)\end{array}$ & $\begin{array}{c}-0.128^{* *} \\
(-1.97)\end{array}$ & $\begin{array}{l}0.035 \text { ** } \\
(1.95)\end{array}$ & $\begin{array}{l}0.182 * \\
(1.82)\end{array}$ & $\begin{array}{l}0.188^{*} \\
(1.81)\end{array}$ \\
\hline Z*if_indu & $\begin{array}{l}0.004^{* *} \\
(1.97)\end{array}$ & $\begin{array}{l}0.585 \\
(0.52)\end{array}$ & $\begin{array}{l}0.043^{*} \\
(1.86)\end{array}$ & $\begin{array}{l}0.781 \text { * } \\
(1.82)\end{array}$ & $\begin{array}{c}0.394 \text { ** } \\
(1.99)\end{array}$ & $\begin{array}{l}0.068 \\
(0.68)\end{array}$ & $\begin{array}{c}-0.008^{* *} \\
(-1.96)\end{array}$ & $\begin{array}{l}-0.701 \text { * } \\
(-1.82)\end{array}$ & $\begin{array}{c}-0.099 * * \\
(-1.96)\end{array}$ & $\begin{array}{c}0.018 \text { ** } \\
(1.99)\end{array}$ & $\begin{array}{l}0.057^{*} \\
(1.85)\end{array}$ & $\begin{array}{l}0.002 \\
(1.67)\end{array}$ \\
\hline$Z^{*}$ if_cons & $\begin{array}{c}0.118 \text { ** } \\
(2.00)\end{array}$ & $\begin{array}{l}0.058 \\
(0.67)\end{array}$ & $\begin{array}{c}0.744^{* *} \\
(1.99)\end{array}$ & $\begin{array}{l}0.861 * \\
(1.84)\end{array}$ & $\begin{array}{l}0.047 \\
(1.51)\end{array}$ & $\begin{array}{l}0.032 \\
(0.83)\end{array}$ & $\begin{array}{c}-0.177^{* *} \\
(-1.98)\end{array}$ & $\begin{array}{l}-0.025 * \\
(-1.79)\end{array}$ & $\begin{array}{c}-0.115^{* *} \\
(-1.94)\end{array}$ & $\begin{array}{l}0.133 * \\
(1.81)\end{array}$ & $\begin{array}{l}0.215^{*} \\
(1.82)\end{array}$ & $\begin{array}{l}0.032 * \\
(1.80)\end{array}$ \\
\hline$Z^{*}$ if_serv & $\begin{array}{c}0.063 \text { ** } \\
(1.90)\end{array}$ & $\begin{array}{l}0.929 \\
(0.49)\end{array}$ & $\begin{array}{c}1.041 \\
* * * \\
(2.19)\end{array}$ & $\begin{array}{l}1.011 \\
(1.52)\end{array}$ & $\begin{array}{c}0.571^{* *} \\
(1.95)\end{array}$ & $\begin{array}{l}0.100 \\
(0.70)\end{array}$ & $\begin{array}{c}0.988^{* * *} \\
(2.84)\end{array}$ & $\begin{array}{l}-0.701 \text { * } \\
(-1.86)\end{array}$ & $\begin{array}{c}-0.159 * * \\
(-1.96)\end{array}$ & $\begin{array}{l}0.162 * \\
(1.85)\end{array}$ & $\begin{array}{l}0.014 \text { * } \\
(1.80)\end{array}$ & $\begin{array}{l}0.232 * \\
(1.87)\end{array}$ \\
\hline $\mathrm{Z}$ & $\begin{array}{l}0.082 \text { ** } \\
(1.99)\end{array}$ & $\begin{array}{l}0.180 * \\
(1.77)\end{array}$ & $\begin{array}{l}1.036^{*} \\
(1.84)\end{array}$ & $\begin{array}{l}-0.284^{*} \\
(-1.79)\end{array}$ & $\begin{array}{c}-0.202 * * \\
(-1.97)\end{array}$ & $\begin{array}{l}-0.052 * \\
(-1.75)\end{array}$ & $\begin{array}{c}-0.018 \text { ** } \\
(-2.01)\end{array}$ & $\begin{array}{l}-0.186^{*} \\
(-1.78)\end{array}$ & $\begin{array}{c}-0.171 * * * \\
(-2.31)\end{array}$ & $\begin{array}{c}0.043^{* * *} \\
(2.18)\end{array}$ & $\begin{array}{l}0.083 * \\
(1.85)\end{array}$ & $\begin{array}{c}0.020 * * * \\
(2.13)\end{array}$ \\
\hline control & yes & yes & yes & yes & yes & yes & yes & yes & yes & yes & yes & yes \\
\hline province & yes & yes & yes & yes & yes & yes & yes & yes & yes & yes & yes & yes \\
\hline time & yes & yes & yes & yes & yes & yes & yes & yes & yes & yes & yes & yes \\
\hline
\end{tabular}

\subsection{Implications of the Empirical Results}

This study proves that China's ETS policy in the seven pilot provinces and cities has indeed achieved the "Porter effect" and discusses the heterogeneity of the development levels in different provinces and cities. Compared with the existing literature, there are two major contributions in this study. The first is the research method. To systematically evaluate the policy effect of China's ETS pilot projects, the PSM-DID method was combined with the DDD method, and a variety of matching methods and different placebo tests were adopted in the empirical analysis. This approach allowed the study to avoid the endogeneity problems existing in traditional measurement methods, thus improving the policy effect. Furthermore, it also allowed for further study of the common trend violation of the DID method, thus expanding the breadth of the policy effect. The second is the research field. Although there have been studies on the "Porter effect" of China's ETS pilot policy, there have been no definitive conclusions yet, and few publications that have discussed the policy effect of the economic development differences and industrial development differences of provinces and cities. On the basis of proving the existence of the "Porter effect" of the policy without the hysteresis effect and declining effect, we further prove that the policy has a stronger inhibitory effect on carbon emissions in the provinces and cities with higher levels of economic and service development, and it has a weaker inhibitory effect on the carbon emissions in the provinces and cities with higher levels of industrial and construction development. Regardless of the economic and industrial development differences, there is no significant impact on the economic effect of the policy. Previous studies that analyzed the impact of enterprise heterogeneity on the ETS policy showed that listed enterprises and state-owned enterprises had achieved better "policy welfare." This study holds that provinces and cities with higher levels of economic and service development have also achieved stronger carbon reduction effects, and the development level of the service industry is the decisive factor for economic development. The results indicate that the policy is conducive to the development of entities with better qualities by comparing the enterprise, economic, and industrial aspects. Therefore, this study could provide an effective basis for China to build a national carbon market by considering the imbalance of the development in the different provinces and cities and providing a reasonable reference for the successful completion of the industrial transformation and connection with national policies. Furthermore, this work fills the research gap on the heterogeneity of the policy effects that are caused by the developmental differences of provinces and cities.

Although this paper further studies the impact of heterogeneity on China's ETS pilot policy, it also has some deficiencies. First, the time dimension is not long enough, although it will not affect the basic conclusions. Future research should extend the time period of the data to eliminate the interference 
caused by various factors in the initial stage of the policy's implementation and enhance the robustness of the empirical results. Second, there is a lack of comparative analysis. In the future, different methods can be adopted to analyze the relevant policy effects on the treatment of sulfur dioxide, carbonitride and other pollutants, as well as the policy effects of the ETS in the relevant countries and regions. This can establish a complete and systematic evaluation system and propose a series of more accurate and effective policy suggestions, which will be future research directions.

\section{Conclusions and Policy Implications}

Starting from 2013 to 2014, China formally launched an ETS pilot project in the seven provinces and cities of Beijing, Tianjin, Shanghai, Chongqing, Guangdong, Hubei, and Shenzhen, and it planned to gradually expand the pilot to a national ETS in 2017, which would replace the EU ETS as the largest ETS in the world. Therefore, studying the policy effects of the ETS pilot will provide important enlightenment on the establishment of the national ETS [15]. This study selected 30 provincial panel data from 2005 to 2017 and used the PSM-DID model to analyze the policy effect of the ETS pilot. Then, the DDD model was introduced to further study the impact of the heterogeneity of the economic and industrial differences on the policy. The empirical conclusions can be summarized as follows:

(1) China's ETS pilot policy has achieved the "Porter effect," but due to the incomplete mechanism and short establishment time, it is necessary to add key control variables to improve the robustness of the results. The study finds that the policy increases GDP by $6.4 \%$ while reducing carbon emissions by $10.0 \%$, and it can be found from the dynamic effect table that the carbon reduction effect and economic effect remain stable over a certain range.

(2) The analysis of the mechanism of the effect of a single control variable shows that the population, carbon intensity, and per capita GDP have major positive effects on carbon emissions. However, the environmental pollution control intensity, research structure and research intensity have negative effects. Finally, the capital stock, employment and energy consumption have significant positive economic effects.

(3) After adding dummy variables for the economic and industrial differences, the coefficient of the interaction term in the DID model is found to be significant, which indicates that it is necessary to introduce the DDD model to further analyze the impact of heterogeneity on the final effect of the policy. Empirical analysis shows that compared with the provinces with lower levels of economic development, the ETS pilot policy has a stronger inhibitory effect on the carbon emissions in the provinces with higher levels of economic development. Compared with the provinces with lower levels of industrial and construction development, the pilot policy has a weaker inhibitory effect on the carbon emissions in the provinces with higher levels of industrial and construction development. Finally, compared with the provinces with lower levels of service development, the pilot policy has a stronger inhibitory effect on the carbon emissions in provinces with higher levels of service development. The levels of economic and industrial development have no significant impacts on the economic effect of the policy.

(4) In recent years, the reductions of the industrialization rate, carbon intensity, and energy structure and the increases of the environmental regulation intensity, research structure, and research intensity in the pilot provinces have generated emissions reduction effects. The economic effect comes from the increased capital, employment, and energy consumption. Compared with the provinces with lower levels of economic and industrial development, the population, carbon intensity and per capita GDP of the provinces with high levels of development have positive effects on carbon emissions, while the environmental pollution control intensity, research structure and research intensity have negative effects on carbon emissions. The level of economic and industrial development has no significant impacts on the economic effect of the policy. 
As a policy tool to control greenhouse gas emissions, according to the total quota setting and allocation scheme, the baseline method and the historical intensity method can be used as the standards to reduce carbon emissions by forcing enterprises to save energy and enhance efficiency, thereby improving the output value of their products and achieving energy conservation and emission reduction. Based on the relevant research results of this study, the related policy recommendations are as follows:

(1) Establish a reasonable initial carbon quota allocation and ETS. The conclusion of the PSM-DID model shows that ETS has indeed achieved economic and environmental benefits in China's carbon trading pilot provinces and cities, that is, the "Porter effect" has been achieved, but a sound and clear carbon trading allocation mechanism is required as a prerequisite. The "Porter effect" of the ETS policy is based on the fact that it can encourage enterprises to independently develop energy-conversation and emissions-reduction technologies and increase the added value of their products. Advanced enterprises can trade surplus carbon quotas to make up for their "innovation cost" and realize "environmental welfare" and "economic welfare." Therefore, it is an essential system guarantee to reasonably allocate carbon quotas and set effective carbon price ranges based on accurate historical emissions statistics and the green technology investment of various enterprises.

(2) The results of the DDD model in this paper indicate that differences in economic development and industrial development will affect the carbon emissions reduction effect of ETS. Due to the economic development and industrial development differences, such as those in the industry, service and construction in different regions and enterprises, the national ETS can achieve a successful connection and smooth transition with regions only by sticking to the unified nationwide operations and management, increasing trade transparency, formulating a strict supervision mechanism, and seeking a balance between equity and efficiency

(3) Compared with a carbon tax, an ETS has a better emissions reduction effect, but the social costs are higher. Based on the mechanism analysis, relevant measures should be formulated according to the key factors, such as the carbon intensity, energy structure, environmental regulation investments, and research factors. For instance, intensifying efforts to develop renewable energy, utilize carbon capture and storage technology (denoted as CCS), advocate for the use of environmental protection materials and services, and provide "innovation compensation" to key $R \& D$ institutions can reasonably control the total costs.

Author Contributions: H.Z. contributed to the study design and drafting of the manuscript. R.Z. and G.L. edited the manuscript. W.L. and Y.C. reviewed the manuscript.

Funding: This work was supported by the National Natural Science Foundation of China $(71373170,71774105)$ and by the National Research Foundation of Korea (Grant No. NRF-2019R1A2C1005326).

Conflicts of Interest: The authors declare no conflict of interest. 


\section{Appendix A}

Table A1. Industry coverage of seven ETS pilots.

\begin{tabular}{|c|c|c|c|}
\hline Pilot & Industry Coverage & Standard & Quantity \\
\hline Shenzhen & $\begin{array}{l}\text { Industry (electricity, water, manufacturing etc.) construction } \\
\text { (industry \& construction) }\end{array}$ & $\begin{array}{l}\text { Industry: above } 5000 \mathrm{t} \\
\text { Public buildings: above } \\
20,000 \mathrm{~m}^{2} \\
\text { Office building: above } \\
1000 \mathrm{~m}^{2}\end{array}$ & $\begin{array}{c}\text { industry: } 635 \\
\text { construction: } 197\end{array}$ \\
\hline Beijing & $\begin{array}{l}\text { Electricity, Thermal, Cement, Petrochemical, Other Industries } \\
\text { and Service industry (industry \& services industry) }\end{array}$ & $\begin{array}{l}\text { Annual emission: above } \\
10,000 \mathrm{t}\end{array}$ & 543 \\
\hline Shanghai & $\begin{array}{l}\text { Industry: electricity, steel, petrochemical, chemical, } \\
\text { non-ferrous, building materials, textiles, rubber and chemical } \\
\text { fibers; non-industrial industry: aviation, airport, port, } \\
\text { shopping mall, hotel, commercial office buildings and railway } \\
\text { stations (industry \& construction \& service industry) }\end{array}$ & $\begin{array}{l}\text { Industry: above } 20,000 \mathrm{t} \\
\text { Non-industry: above } \\
10,000 \mathrm{t}\end{array}$ & 191 \\
\hline Guangdong & Electricity, cement, steel, petrochemical (industry) & $\begin{array}{l}\text { Annual emission: above } \\
20,000 \mathrm{t}\end{array}$ & 193 \\
\hline Tianjin & $\begin{array}{l}\text { Electricity, thermal, steel, petrochemical, oil and gas } \\
\text { exploitation (industry) }\end{array}$ & $\begin{array}{l}\text { Annual emission: above } \\
20,000 \mathrm{t}\end{array}$ & 114 \\
\hline Hubei & $\begin{array}{l}\text { Electricity, glass, electrolytic aluminium, calcium carbide, } \\
\text { papermaking, automobile manufacturing, steel, titanium alloy, } \\
\text { synthetic ammonia, cement, petroleum processing (industry) }\end{array}$ & $\begin{array}{l}\text { Annual Comprehensive } \\
\text { Energy Consumption: } \\
60,000 \text { t Standard Coal }\end{array}$ & 138 \\
\hline Chongqing & $\begin{array}{l}\text { Industrial enterprises, excluding construction and } \\
\text { transportation (industry) }\end{array}$ & $\begin{array}{l}\text { Annual } \mathrm{CO}_{2} \text { equivalent } \\
\text { emission: } 20,000 \text { t any } \\
\text { year in } 2008-2012\end{array}$ & 242 \\
\hline
\end{tabular}

\section{References}

1. Fan, X.H.; Li, X.X.; Yin, J.L.; Tian, L.X.; Liang, J.C. Similarity and heterogeneity of price dynamics across China's regional carbon markets: A visibility graph network approach. Appl. Energy 2019, 235, 739-746. [CrossRef]

2. Simone, B.; Massimiliano, M. The best (and worst) of GHG Emission Trading Schemes: Comparing the EU ETS with its followers. Front. Energy Res. 2016, 4-27. [CrossRef]

3. Dong, J.; Ma, Y.; Sun, H.X. From Pilot to the National Emissions Trading Scheme in China: International Practice and Domestic Experiences. Sustainability 2016, 8, 522. [CrossRef]

4. Raphael, C.; Antoine, D. Environmental Policy and Directed Technological Change: Evidence from the European Carbon Market. Rev. Econ. Stat. 2016, 98, 173-191. [CrossRef]

5. Yan, Y.F. Evaluation of the impact of global carbon trading market on China's economy-energy-climate system. China Popul. Resour. Environ. 2015, 25, 32-39. [CrossRef]

6. Shi, M.J.; Yuan, Y.N.; Zhou, Y.L.; Li, N. Carbon emission reduction policy: carbon tax, carbon trading or both? J. Manag. Sci. 2013, 16, 9-19.

7. Ren, S.G.; Zheng, J.J.; Liu, D.H.; Chen, X.H. Does the Emission Trading Mechanism Improve the Total Factor Productivity of Enterprises-Evidence from Chinese Listed Companies. China Ind. Econ. 2019, 5, 5-23.

8. Qian, H.Q.; Zhou, Y.; Wu, L.B. Evaluating various choices of sector coverage in China's national emissions trading system (ETS). Clim. Policy 2018, 18, 1-20. [CrossRef]

9. Porter, M.E. America's green strategy. Sci. Am. 1991, 264, 193-246. [CrossRef]

10. Porter, M.E.; Linde, C.V.D. Toward a new conception of the environment competitiveness relationship. J. Econ. Perspect. 1995, 9, 97-118. [CrossRef]

11. Gollop, F.; Robert, M. Environmental regulations and productivity growth: the case of fossil-fueledelectric power generation. J. Political Econ. 1983, 91, 654-655. [CrossRef]

12. Jorgenson, D.W.; Wilcoxen, P.J. Environmental regulation and U.S. economic growth. Rand J. Econ. 1990, 21, 313-340. [CrossRef]

13. Zhang, C.; Wang, Q.; Shi, D. Scenario-based potential effects of carbon trading in China: an integrated approach. Appl. Energy 2016, 182, 177-190. [CrossRef] 
14. Wang, H.; Chen, Z.P.; Wu, X.Y.; Nie, X. Can a carbon trading system promote the transformation of a low-carbon economy under the framework of the porter hypothesis?-Empirical analysis based on the PSM-DID method. Energy Policy 2019, 129, 930-938. [CrossRef]

15. Zhou, B.; Zhang, C.; Song, H.Y.; Wang, Q.W. How does emission trading reduce China's carbon intensity? An exploration using a decomposition and difference-in-differences approach. Sci. Total Environ. 2019, 676, 514-523. [CrossRef] [PubMed]

16. Dong, F.; Dai, Y.J. Can a carbon emission trading scheme generate the Porter effect? Evidence from pilot areas in China. Sci. Total Environ. 2019, 653, 565-577. [CrossRef]

17. Zhang, Y.J.; Peng, Y.L.; Ma, C.Q.; Shen, B. Can environmental innovation facilitate carbon emissions reduction? Evidence from China. Energy Policy 2017, 100, 18-28. [CrossRef]

18. Marina, E.; Andreas, P. EU Emissions Trading scheme in aviation: Policy analysis and suggestions. J. Clean. Prod. 2019, 237, 117734. [CrossRef]

19. Zhang, H.J.; Duan, M.S.; Deng, Z. Have China's pilot emissions trading schemes promoted carbon emission reductions?- the evidence from industrial sub-sectors at the provincial level. J. Clean. Prod. 2019, 234, 912-924. [CrossRef]

20. Gu, Y.W.; Wallace, S.W.; Wang, X. Can an Emission Trading Scheme really reduce $\mathrm{CO}_{2}$ emissions in the short term? Evidence from a maritime fleet composition and deployment model. Transp. Res. Part D 2019, 74, 318-338. [CrossRef]

21. Zhu, L.; Zhang, X.B.; Li, Y.; Wang, X.; Guo, J.X. Can an emission trading scheme promote the withdrawal of outdated capacity in energy-intensive sectors? A case study on China's iron and steel industry. Energy Econ. 2017, 63, 332-347. [CrossRef]

22. Lin, B.Q.; Jia, Z.J. Transfer payments in emission trading markets: A perspective of rural and urban residents in China. J. Clean. Prod. 2018, 204, 753-766. [CrossRef]

23. Bodo, S.; Pei, J.S.; Wang, R.; Andreas, L.; Zhao, Z.X. Conditional cooperation in case of a global public good-Experimental evidence from climate change mitigation in Beijing. China Econ. Rev. 2019, 56, 101308. [CrossRef]

24. Fan, X.H.; Li, X.X.; Yin, J.L.; Tian, L.X.; Liang, J.C. Multifractality and market efficiency of carbon emission trading market: Analysis using the multifractal detrended fluctuation technique. Appl. Energy 2019, 251, 113333. [CrossRef]

25. Song, Y.Z.; Liu, T.S.; Ye, B.; Zhu, Y.; Li, Y.; Song, X.Q. Improving the liquidity of China's carbon market: Insight from the effect of carbon price transmission under the policy release. J. Clean. Prod. 2019, 239, 118049. [CrossRef]

26. Lin, B.Q.; Jia, Z.J. What are the main factors affecting carbon price in Emission Trading Scheme? A case study in China. Sci. Total Environ. 2019, 654, 525-534. [CrossRef]

27. Zhao, X.G.; Jiang, G.W.; Nie, D.; Chen, H. How to improve the market efficiency of carbon trading: A perspective of China. Renew. Sustain. Energy Rev. 2016, 59, 1229-1245. [CrossRef]

28. Choi, Y.; Lee, H.S. Are Emissions Trading Policies Sustainable? A Study of the Petrochemical Industry in Korea. Sustainability 2016, 8, 1110. [CrossRef]

29. Sun, J.C.; Du, T.; Sun, W.Q.; Na, H.M.; He, J.F.; Qiu, Z.Y.; Yuan, Y.X.; Li, Y.N. An evaluation of greenhouse gas emission efficiency in China's industry based on SFA. Sci. Total Environ. 2019, 690, 1190-1202. [CrossRef]

30. Lin, B.Q.; Jia, Z.J. The impact of Emission Trading Scheme (ETS) and the choice of coverage industry in ETS: A case study in China. Appl. Energy 2017, 205, 1512-1527. [CrossRef]

31. Tang, L.; Wu, J.Q.; Yu, L.A.; Bao, Q. Carbon allowance auction design of China's emissions trading scheme: A multi-agent-based approach. Energy Policy 2017, 102, 30-40. [CrossRef]

32. Yang, Z.B.; Fan, M.T.; Shao, S. Does carbon intensity constraint policy improve industrial green production performance in China? A quasi-DID analysis. Energy Econ. 2017, 68, 271-282. [CrossRef]

33. Tu, Z.G.; Chen, R.J. Can the Emissions Trading Mechanism Realize the Porter Effect in China? Econ. Res. 2015, 50, 160-173.

34. Liu, W.; Zhang, X.C. Carbon Emission Trading System and Enterprise R\&D Innovation-An Empirical Study Based on Triple Difference Model. Econ. Sci. 2017, 3, 102-114.

35. Ashenfelter, O.; Card, D. Using the longitudinal structure of earnings to estimate the effect of training programs. Rev. Econ. Stat. 1984, 67, 648-660. [CrossRef] 
36. Meyer, B.D. Natural and quasi-experiments in economics. Bus. Econ. Stat. 1995, 13, 151-161. [CrossRef]

37. Sunak, Y.; Madlener, R. The impact of wind farm visibility on property values: A spatial difference-in-differences analysis. Energ Econ. 2016, 55, 79-91. [CrossRef]

38. Shen, H.T.; Huang, N.; Liu, L. A study of the micro-effect and mechanism of the carbon emission trading scheme. J. Xiamen Univ. 2017, 1, 13-22.

39. Locke, C.M.; Butsic, V.; Rissman, A.R. Zoning effects on housing change vary with income, based on a four-decade panel model after propensity score matching. Land Use Policy 2017, 64, 353-362. [CrossRef]

40. Zhang, Y.; Zhang, J.K. Estimating the impacts of emissions trading scheme on low-carbon development. J. Clean. Prod. 2019, 238, 1-8. [CrossRef]

41. Zhou, Y.; Jiang, J.J.; Ye, B.; Zhang, Y.M.; Yan, J. Addressing climate change through a market mechanism: A comparative study of the pilot emission trading schemes in China. Environ. Geochem. Health 2019, 2, 1-23. [CrossRef]

42. Wang, Q.; Gao, C.Y. Study on the effect of carbon trading system on China's avoidance of carbon traps and promotion of carbon decoupling. China Popul. Resour. Environ. 2018, 28, 16-23. [CrossRef]

(C) 2019 by the authors. Licensee MDPI, Basel, Switzerland. This article is an open access article distributed under the terms and conditions of the Creative Commons Attribution (CC BY) license (http://creativecommons.org/licenses/by/4.0/). 